\title{
CCND3 Protein Overexpression
}

National Cancer Institute

\section{Source}

National Cancer Institute. CCND3 Protein Overexpression. NCI Thesaurus. Code

C141368.

A molecular abnormality indicating the presence of an abnormally high level of the G1/Sspecific cyclin-D3 protein. 